Article type : Review Article

\title{
-The role of the dermatologist in Raynaud's Phenomenon: a clinical challenge
}

Caterina Matucci-Cerinic ${ }^{1}$, Vivek Nagaraja ${ }^{2}$, Francesca Prignano ${ }^{1}$, Bashar Kahaleh ${ }^{3}$, Silvia Bellando-Randone ${ }^{4}$

${ }^{1}$ Dermatology Clinic - ASF, Department of Surgery and Translational Medicine, University of Florence, florence, Italy

${ }^{2}$ Department of Medicine, Division of Rheumatology, University of Michigan, Ann Arbor , Michigan USA

3.Department of Medicine, Division of Rheumatology, University of Toledo, Toledo, USA 4.Department of Experimental and Clinical Medicine, University of Florence \& Department of Geriatric Medicine, Division of Rheumatology AOUC, Florence, Italy

Correspondence to: Caterina Matucci-Cerinic ${ }^{1}$

Address: $\quad$ via P. Thouar 16, 50122, Florence, Italy

Email: $\quad$ c.matuccicerinic@gmail.com

Phone: $\quad+393408696746$

Fax: $\quad+390552343559$

Funding: No relevant grant funding to disclose

Conflicts of interest: None

Acknowledgements: None

This is the author manuscript accepted for publication and has undergone full peer review but has not been through the copyediting, typesetting, pagination and proofreading process, which may lead to differences between this version and the Version of Record. Please cite this article as doi: $10.1111 / \mathrm{jdv} .14914$

This article is protected by copyright. All rights reserved 
- Word length for the article's text (not including title page, abstract, abbreviations, references, tables, figures, or appendices): 2140

- Abstract word count: 207

- Number of references: 34

- Number of tables: 5

- Number of figures: 4

\section{Abstract}

Raynaud's phenomenon (RP) is a functional vascular disorder involving extremities. In his practice, the dermatologist may frequently encounter RP which affects mainly women and is categorized into a primary benign form and a secondary form associated with different diseases (infections, drugs, autoimmune and vascular conditions, hematologic, rheumatologic and endocrinologic disorders). Still today, the differential diagnosis is a clinical challenge. Therefore, a careful history and a physical examination, together with laboratory tests and nailfold capillaroscopy are mandatory. RP is generally benign but a scheduled follow-up for primary RP patients should be established, due to risk of evolution to secondary RP

A combination of conservative measures and medications can help in the management of RP. The importance of avoiding all potential physical, chemical and emotional triggers, as well as quitting smoking should be strongly suggested to the patient. As first line treatment, dihydropyridine Calcium Channel Blockers should be used. If this approach is not sufficient, prostacyclin derivatives, phosphodiesterases inhibitors and endothelin receptor antagonists can be considered as second line treatment. In cases of acute ischemia nifedipine and intravenous prostanoidsare helpful. In refractory cases, botulinum injections have shown a significant benefit. The approach to the RP patients requires therefore a coordinated care of specialists together with the primary care physician.

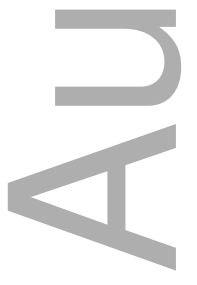




\section{Introduction}

Raynaud's phenomenon (RP) is frequently encountered by the dermatologist in his practice and represents today a clinical challenge. It is defined as a bi- or tri-phasic color change of hands, feet, nose, earlobes and tongue, characterized by blanching (ischemia) followed by cyanosis (anoxia) and later by rubor (reperfusion) (Figure 1). Pallor is the most specific sign and rubor is the least specific. RP can affect one or more digits; it is painful, intermittent, and lasts from few minutes to several hours. Currently RP is classified as a primary RP (pRP) that usually has a benign course, and secondary RP (sRP) that is associated with multiple etiologies.

The aim of our work is to focus on the main problems that the dermatologist may have in managing RP in clinical practice.

\section{Frequency of Raynaud's phenomenon}

The prevalence of RP is variable, ranging between $4 \%-15 \%$. There are inconsistencies in the prevalence rate across geographical areas due to differences in the diagnostic methods, climate characteristics, and ethnicity within various populations (1). A higher prevalence of RP has been described in younger women. In a large USA study with a 16years follow up, $9.6 \%$ of the women and $8.1 \%$ of men developed pRP (2). In another study, the population-based annual prevalence rates of RP was estimated as $3.6 \%$ for women and $1.4 \%$ for men, with women clearly having a higher risk for $\operatorname{RP}(3)$. The risk of RP was shown to increase consistently, yet modestly, with age (over 35 years), and decrease constantly with the decreased body mass index. (3)

\section{Triggers}

$\mathrm{RP}$ is usually triggered by an abrupt fall of temperature or by emotional stress. Moving from a warm environment to a colder one (outdoors in winter or air conditioned room in summer) can trigger RP attacks. There are many secondary triggers for RP - (i) cigarette smoking(4), (ii) medications (5), (iii) caffeine, (iv) occupations involving the constant use of vibrating tools or cold substances with an exponential increase in the risk after 12-years of work (3), (v) exposure to chlorinated and non-chlorinated solvents [acetone, toluene, xylene, etc.](6).

\section{Approach to the evaluation of Raynaud's phenomenon}


When a patient complains of blanching fingers followed by cyanosis and rubor, a methodological approach is required (Figure 2). The first step is to confirm the diagnosis of RP. This can be accomplished by a careful clinical history and physical examination. Most patients may not have active RP at the time of evaluation; thus it is helpful to verify $\mathrm{RP}$ by inspecting photographs taken by the patient at the time of an attack or by the use of color charts that enable the patient to confirm the typical color changes (7). The next step is to determine if RP is pRP or sRP: a detailed history to identify possible etiologies, a careful physical examination, laboratory tests and nailfold capillaroscopy (NC) are essential at this stage.

Primary $\boldsymbol{R P}$ is due to an exaggerated vasospastic response to cold or other stimuli and usually occurs in young women (8). It is characterized by symmetrical attacks of short duration (few minutes) in absence of any specific skin lesion (like digital ulcerations or scars), internal organ involvement or acral vascular complication. Apart from the history of $\mathrm{RP}$ upon exposure to any stimuli, the rest of the history and physical examination is usually unremarkable, including normal NC. (9)

Secondary RP may involve both hands and may be, at the very onset, affecting only one finger. Usually, it is painful and lasts longer than pRP. It is suspected when the symptoms' onset is over 30 years and/or complications occur [e.g. digital ulcers (DUs), pitting scars (8), secondary infection, tissue gangrene and auto or surgical amputation (10) (Figure 3)]. (Table I details the differences between pRP and sRP)

Personal history and clinical examination help in identifying potential causes of SRP (see Table II) - occupational and environmental factors, smoking, medications (Table III), symptoms and signs suggestive of a connective tissue disease (CTD), vascular disease, hematologic condition or infectious disease.

A targeted laboratory work-up (autoantibodies and other serologies) may be helpful in identifying the cause. Further investigations, when needed, are guided by clinical evaluation. (The differential diagnosis are summarized in Table IV).

Since approximately 10 to $30 \%$ of RP patients can develop a CTD (11-13), it is important to establish a scheduled follow-up with laboratory tests (e.g. complete blood count, erythrocyte sedimentation rate, chemistry, and autoimmune panel). An abnormal baseline 
NC and/or abnormal serology (antinuclear, anticentromere or anti-Scl70 antibodies) are the best predictors for this progression.

Among all CTDs, the most frequently developed disease is Systemic Sclerosis (SSc). (14) A study of 586 patients with RP without definite CTD reported that $12.6 \%$ developed SSc after a median duration of a 4-years follow-up. The presence of a scleroderma pattern at $\mathrm{NC}$, and the presence of anti-nuclear (ANA), anti-centromere (ACA) and/ or anti topoisomerase-I antibodies (anti-Scl70) independently predicted the evolution to SSc(11). However, these signs together with puffy fingers suggest a diagnosis of very early SSc, thus warranting further investigation of internal organs (15). Therefore, patients with RP and abnormal NC or positive serology should be labeled as "at risk for CTD" and followed periodically for detecting the potential transition to CTD.

For what concerns other CTDs, a study of 3029 pRP patients reported that $37 \%$ of them developed CTD, the most frequent being an undifferentiated CTD (UCTD), followed by systemic lupus erythematosus, rheumatoid arthritis, Sjögren syndrome, overlap syndrome and systemic vasculitides. (14)

\section{Role of imaging}

Nailfold capillaroscopy (NC) is a very useful technique that can easily be performed with a stereomicroscope or an ophthalmoscope to identify microvascular changes suggestive of CTD. A scleroderma pattern (giant capillaries, micro-hemorrhages, architectural modifications and avascular areas) is typically found in SSc (Figure 4)(16) and in a good proportion of patients with dermatomyositis (DM), with a high sensitivity and specificity $(14,17,18)$. In contrast, in other CTDs (polymyositis (PM), systemic lupus erythematosus (SLE), Sjögren syndrome (SjS), rheumatoid arthritis (RA) and systemic vasculitides normal capillaries or non specific changes (such as elongated or enlarged capillaries or a slight capillary loss), are generally found, and cannot therefore be considered as predictive of the disease (14). Interestingly, a lack of association was found between the clinically involved digits and the degree of alterations seen at NC (19).

When RP is asymmetric and tissue lesions are present in the digits, Doppler ultrasound may help to identify pathologic modifications of the arterial circulation, particularly in the ulnar arteries. However, the involvement of the digital arteries is difficult to demonstrate with Doppler, despite the fact that it is present in $63 \%$ of sRP and in $6 \%$ of pRP patients (20). In recurrent and complicated cases of sRP, conventional angiography or Magnetic Resonance Angiography (MRA) are the gold standard for the assessment of the 
macrovasculature (21). These investigations are recommended to evaluate the potential of large to medium artery pathology, as seen in atherosclerosis, Takayasu vasculitis, and Buerger's disease. These disorders are characterized by limb claudication on exercise, asymmetric abnormalities or an isolated and persistent digital ischemia, that can mimic $\mathrm{RP}$.

\section{Role of outcome measures}

There has been a great deal of interest in developing disease activity and outcome measures in the clinical trial setting (22). In RP clinical trials, patients are usually advised to maintain a diary to record the frequency and duration of RP attack, and at the end of each day they are advised to complete a Raynaud's Condition Score (RCS). The RCS is a daily self-assessment of RP activity using a $0-10$ ordinal scale. RCS incorporates the cumulative daily frequency, duration, severity, and impact of RP attacks on hand function. Other measures include patient and physician assessments of RP. However, the efficacy of these outcome measures has been fairly variable largely due to the subjective nature of the measures and also due to the placebo effect. A combination of items has been shown to be associated with lower placebo responses (23).

\section{Treatment of Raynaud's phenomenon}

The initial management of RP aims to avoid RP triggers and to adapt lifestyle to patient's need (24). Patients are advised to avoid or minimize cold exposure and thermal excursions, to dress warm and to have adequate insulation during cold weather and to keep their hands and feet warm with gloves and appropriate footwear. It is important to emphasize the value of quitting smoking. Patients should try to avoid emotional triggers, physical or chemical triggers and medications thought to cause RP. In most cases of pRP, pharmacotherapy is not required and lifestyle modifications are sufficient may control the symptoms (25). In contrast, pharmacological therapy, single or combined, is often needed in SRP.

\section{Pharmacological therapy}

Recently, new recommendations have been issued focusing mainly on calcium channel blockers (CCBs), prostacyclin derivatives, Inhibitors of phosphodiesterases and endothelin receptor antagonists (25). 
CCBs, especially dihydropyridine type CCBs, are the most commonly used group of medications as a first line treatment of RP. They relax vascular smooth muscle cells leading to vasodilation, and they also reduce platelet activation. They have been shown to reduce the number and severity of RP attacks and its complications. Nifedipine has been the most extensively studied (26) and recommended as the first line therapy to reduce the frequency and severity of RP in SSc patients (25). The newer second-generation CCBs (amlodipine, isradipine, nicardipine, felodipine) are also effective in reducing RP attacks. The treatment should start with a low dosage and titrated based on the tolerance and side effects in the individual patient. Common side effects of CCBs include headache, significant reduction of systemic blood pressure or peripheral edema. Based on the available evidence, oral CCBs like nifedipine or amlodipine should be used as initial choice of pharmacotherapy.

If the therapy with CCBs is not effective in controlling the attacks, other therapies are recommended (Table $\mathbf{V}$ ) and an expert consultation should be obtained for further care. In patients who have to use a beta-blocker for cardiac indications, it is preferable to avoid the use of beta2-blockers (non-cardio selective) and use beta1-blockers (cardio selective) like carvedilol, labetalol and nebivolol although there are rare case reports of RP related to the use of beta1-blockers. $(27,28)$. Gingko Biloba, herbal medications, acupuncture and other alternative therapies (laser and nutritional supplements) did not prove to impact the frequency, duration and severity of $\operatorname{RP}(29)$. Moreover, temperature biofeedback is reported to be less efficacious than nifedipine in treating $\mathrm{RP}(30)$. Recently, a pilot singlecenter, randomised controlled trial of acupressure versus targeted patient education in primary and secondary RP did not show any efficacy for this technique (31). Recently, the use of ischemic preconditioning, which was thought to help potentially patients with RP, reducing the number of attacks, was found ineffective (32)

\section{Emergencies in Raynaud's phenomenon- the threatened digit}

Patients with chronic SRP, especially in the setting of CTD, can have episodes of acute digital or limb ischemia, which can rapidly progress to necrosis and gangrene. Early recognition and prompt vasodilating therapy is the key to avoid tissue loss. A detailed vascular examination is helpful; if peripheral pulses are feeble or absent, vascular imaging and vascular surgery consultation to assess the need for angioplasty/vascular intervention is needed to secure vessel potency and blood flow to the extremities. Nifedipine may be started in high dosages (30 mg four times a day) and in extreme situations, when digit or 
limbs are at risk, an intravenous iloprost or epoprostenol infusion combined with anticoagulation (heparin, $5.000 \mathrm{UI}$ twice daily) is preferable. A recent meta-analysis concluded that the use of iloprost in critical limb ischemia was efficacious in terms of pain relief, ulcer healing, and reduced need for amputations (33). These infusions are usually administered in a telemetry equipped wards under the care of cardiologists. Sympathetic block with anesthetics may also achieve a rapid vasodilatation. It is important to use effective analgesia, and local care of DUs with necrotic tissue debridement and infection control with appropriate antibiotics is crucial for full recovery. Therapeutic angiogenesis with autologous stem cells in patients lacking options for revascularization remains to be tested in future large-scale randomized trials (34).

\section{Conclusions}

The diagnosis of RP and categorization into pRP and sRP is very important and is largely a clinical challenge for the dermatologist. Laboratory and imaging investigations are driven by clinical suspicion of secondary causes or due to concerns for peripheral vascular disease, respectively. Non-pharmacological management such as avoidance of RP triggers, peripheral and core re-warming and use of protective clothing are vital. If RP is severe or if ulcers occur, pharmacotherapy may be recommended to control the attacks. In sRP pharmacological therapy is usually needed, CCBs being the first line of treatment (nifedipine or amlodipine most frequently used). If the attacks persist despite maximal doses of CCBs, then other medical therapies are recommended, and referral to a specialist in RP should be considered.

In conclusion, the approach to RP is a coordinated care with various specialists involved along with the primary care physician.

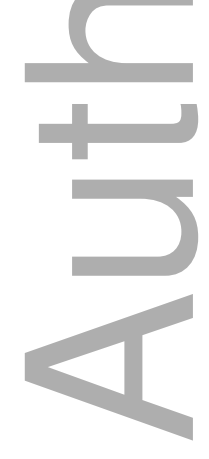

This article is protected by copyright. All rights reserved 


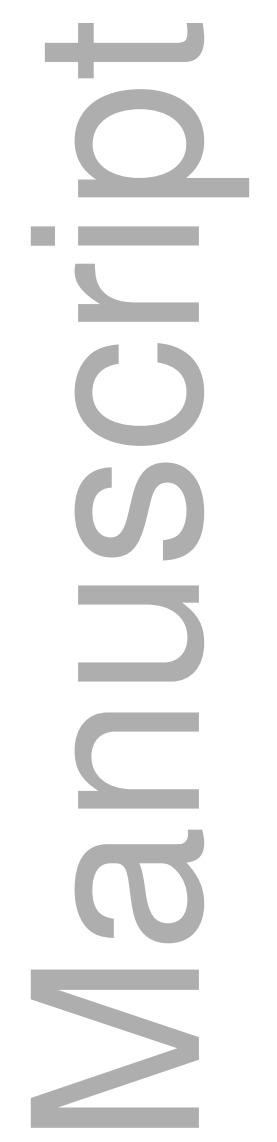

\section{Abbreviations}

$\mathrm{RP}$ : raynaud's phenomenon

pRP: primary raynaud's phenomenon

SRP: secondary raynaud's phenomenon

NC: nailfold capillaroscopy

DU: digital ulcer

CTD: connective tissue disease

SSc: systemic sclerosis

ANA: anti-nuclear antibodies

ACA: anti-centromere antibodies

Anti-Scl70: anti topoisomerase-I antibodies

UCTD: Undifferentiated CTD

SLE: systemic lupus erythematosus

$\mathrm{RA}$ : rheumatoid arthritis

This article is protected by copyright. All rights reserved 
DM: dermatomyositis

PM: polymyositis

SjS: Sjogren syndrome

RCS: Raynaud's Condition Score

MRA: Magnetic Resonance Angiography

CCBs: calcium channel blockers

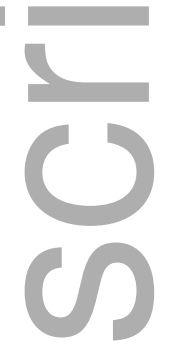

\section{References}

1. Maricq HR, Carpentier PH, Weinrich MC et al. Geographic variation in the prevalence of Raynaud's phenomenon: a 5 region comparison. J Rheumatol. 1997;24(5):879-89.

2. Brand FN, Larson MG, Kannel WB, McGuirk JM. The occurrence of Raynaud's phenomenon in a general population: the Framingham Study. Vascular Med. 1997;2(4):296-301.

3. Roquelaure $\mathrm{Y}, \mathrm{Ha} \mathrm{C}$, Le Manac'h AP et al. Risk factors for Raynaud's phenomenon in the workforce. Arthritis Care Res 2012;64(6):898-904.

4. Bocanegra TS, Espinoza LR. Raynaud's phenomenon in passive smokers. N Engl J Medicine. 1980;303(24):1419.

5. Khouri C, Blaise S, Carpentier $P$ et al. Drug-induced Raynaud's phenomenon: beyond $\beta$ adrenoceptor blockers. Br J Clin Pharmacol. 2016;82(1):6-16.

6. Purdie GL, Purdie DJ, Harrison AA. Raynaud's phenomenon in medical laboratory workers who work with solvents. J Rheumatol. 2011;38(9):1940-6.

7. Maricq HR, Weinrich MC. Diagnosis of Raynaud's phenomenon assisted by color charts. J Rheumatol. 1988;15(3):454-9

8. LeRoy EC, Medsger TA, Jr. Raynaud's phenomenon: a proposal for classification. Clin Exp Rheumatol. 1992;10(5):485-8.

9. Maverakis E, Patel F, Kronenberg DG et al. International consensus criteria for the diagnosis of Raynaud's phenomenon.J Autoimmun. 2014 48-49:60-5

10. Denton CP, Krieg T, Guillevin L et al. Demographic, clinical and antibody characteristics of patients with digital ulcers in systemic sclerosis: data from the DUO Registry. Ann Rheum Dis. 2012;71(5):718-21.

This article is protected by copyright. All rights reserved 
11. Koenig M, Joyal F, Fritzler MJ et al. Autoantibodies and microvascular damage are independent predictive factors for the progression of Raynaud's phenomenon to systemic sclerosis: a twenty-year prospective study of 586 patients, with validation of proposed criteria for early systemic sclerosis. Arthritis Rheum. 2008;58(12):3902-12.

12. Ziegler S, Brunner M, Eigenbauer E, Minar E. Long-term outcome of primary Raynaud's phenomenon and its conversion to connective tissue disease: a 12-year retrospective patient analysis. Scand J Rheumatol. 2003;32(6):343-7.

13. Kallenberg CG, Wouda AA, Hoet MH, van Venrooij WJ. Development of connective tissue disease in patients presenting with Raynaud's phenomenon: a six year follow up with emphasis on the predictive value of antinuclear antibodies as detected by immunoblotting. Ann Rheum Dis. 1988 Aug;47(8):634-41.

14. Pavlov-Dolijanovic S., Damjanov NS, Stojanovic RM et al. Scleroderma Pattern of Nailfold Capillary Changes as Predictive Value for the Development of a Connective Tissue Disease: A Follow-up Study of 3,029 Patients with Primary Raynaud's Phenomenon. Rheumatol Int 2012; 32(10): 3039-3045.

15. Avouac J, Fransen J, Walker UA et al. Preliminary criteria for the very early diagnosis of systemic sclerosis: results of a Delphi Consensus Study from EULAR Scleroderma Trials and Research Group. Ann Rheum Dis. 2011;70(3):476-81.

16. Cutolo M, Grassi W, Matucci Cerinic M. Raynaud's phenomenon and the role of capillaroscopy. Arthritis Rheum. 2003;48(11):3023-30.

17. Nagy Z., Czirják L. Nailfold Digital Capillaroscopy in 447 Patients with Connective Tissue Disease and Raynaud's Disease. JEADV 2004; 18(1): 62-8.

18. Manfredi A, Sebastiani M, Cassone G et al. Nailfold Capillaroscopic Changes in Dermatomyositis and Polymyositis. Clin Rheumatol 2015;34(2): 279-84.

19. Ingegnoli F, Gualtierotti R, Orenti A et al.Uniphasic Blanching of the Fingers, Abnormal Capillaroscopy in Nonsymptomatic Digits, and Autoantibodies: Expanding Options to Increase the Level of Suspicion of Connective Tissue Diseases beyond the Classification of Raynaud's Phenomenon. J Immunol Res 2015: 371960.

20. Porta F, Gargani L, Kaloudi O et al. The new frontiers of ultrasound in the complex world of vasculitides and scleroderma. Rheumatology. 2012;51 Suppl 7:vii26-30.

21. van Vugt RM, Kater L, Dijkstra PF et al. The outcome of angiography in patients with Raynaud's phenomenon: an unexpected role for atherosclerosis and hypercholesterolemia. Clin Exp Rheumatol. 2003;21(4):445-50.

22. Merkel PA, Herlyn K, Martin RW et al. Measuring disease activity and functional status in patients with scleroderma and Raynaud's phenomenon. Arthritis Rheum. 2002;46(9):241020. 
23. Gladue H, Maranian P, Paulus HE, Khanna D. Evaluation of test characteristics for outcome measures used in Raynaud's phenomenon clinical trials. Arthritis Care Res. 2013;65(4):630-6.

24. Herrick AL. Management of Raynaud's phenomenon and digital ischemia. Curr Rheumatol Rep. 2013;15(1):303.

25. Kowal-Bielecka O, Fransen J, Avouac $\mathrm{J}$ et al. Update of EULAR recommendations for the treatment of systemic sclerosis. Ann Rheum Dis. 2017;76(8):1327-1339.

26. Thompson AE, Shea B, Welch V, et al. Calcium-channel blockers for Raynaud's phenomenon in systemic sclerosis. Arthritis Rheum. 2001;44(8):1841-

27. V-lbarra N, de Lara G, Pernias V et al. Raynaud's phenomenon secondary to nebivolol. Archiv Cardiol Mex 2015; 85(4): 342-3.

28. McGuinness N, Cording V. Raynaud's phenomenon of the nipple associated with labetalol use. J Hum Lact. 2013;29(1):17-9.

29. Malenfant D, Catton M, Pope JE. The efficacy of complementary and alternative medicine in the treatment of Raynaud's phenomenon: a literature review and meta-analysis. Rheumatology. 2009;48(7):791-5.

30. Sporbeck B, Mathiske-Schmidt K, Jahr S et al. Effect of biofeedback and deep oscillation on Raynaud's phenomenon secondary to systemic sclerosis: results of a controlled prospective randomized clinical trial. Rheumatol Int 2012;32(5):1469-73.

31. Gladue $\mathrm{H}$, Berrocal V, Harris R et al A Randomized Control Trial of Acupressure for the Treatment of Raynaud's Phenomenon: The difficulty of conducting a trial in Raynaud's J Scleroderma Rel Dis 2016; 1: 226-233

32. Neferu R, Vanderhoel L, Hewitt $S$ et al. A randomized, single-blinded cross-over trial of ischemic preconditioning in Raynaud's phenomenon J scleroderma relat disord 2017; 2(3): $213-20$

33. Ruffolo AJ, Romano M, Ciapponi A. Prostanoids for critical limb ischaemia. Cochrane Database System Rev. 2010(1):CD006544.

34. Guiducci S, Porta F, Saccardi R et al. Autologous mesenchymal stem cells foster revascularization of ischemic limbs in systemic sclerosis: a case report. Ann Int Med. 2010;153(10):650-4.

This article is protected by copyright. All rights reserved 


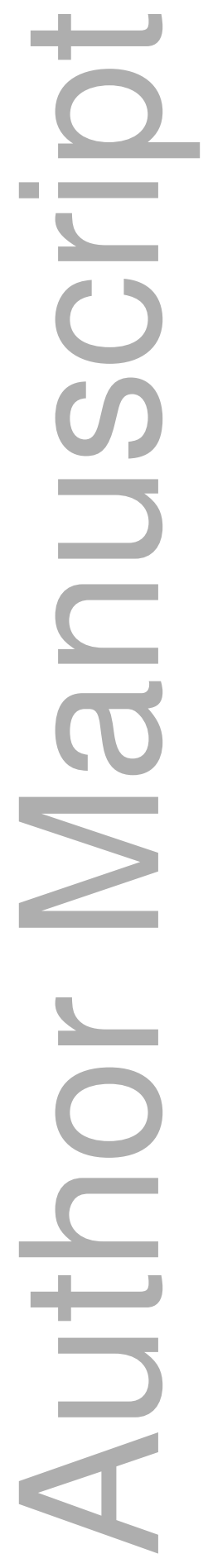

This article is protected by copyright. All rights reserved 
Table I: Classification of Raynaud's phenomenon (RP)

\begin{tabular}{|c|c|}
\hline Primary RP & Secondary RP \\
\hline Young women $[<30$ years] & Patients aged $>30$ years \\
\hline Attacks are symmetric and are of short duration & $\begin{array}{l}\text { Attacks are asymmetric, extremely painful and } \\
\text { prolonged }\end{array}$ \\
\hline $\begin{array}{l}\text { No tissue lesions (digital pitting scars, } \\
\text { telangiectasia) }\end{array}$ & Tissue lesions seen \\
\hline $\begin{array}{l}\text { No complications (digital ulcers, } \\
\text { necrosis/gangrene) on the extremities }\end{array}$ & Local complications common \\
\hline Normal nailfold capillaroscopy & $\begin{array}{l}\text { Abnormal nailfold capillaroscopy in the setting } \\
\text { of CTD }\end{array}$ \\
\hline $\begin{array}{l}\text { Usually no suggestive features of CTD on } \\
\text { clinical evaluation }\end{array}$ & Association with CTD is common \\
\hline Autoantibodies negative & $\begin{array}{l}\text { Autoantibodies could be positive when } \\
\text { associated CTD }\end{array}$ \\
\hline
\end{tabular}

This article is protected by copyright. All rights reserved 


\section{Table II: Causes of secondary RP}

1. Autoimmune/Connective tissue diseases: Systemic Sclerosis, Systemic Lupus Erythematosus, dermatomyositis, polymyositis, Sjogren's syndrome, primary biliary cirrhosis, Rheumatoid Arthritis

2. Arterial diseases: thromboangiitis obliterans (Buerger's disease), Takayasu vasculitis, giant cell arteritis, brachiocephalic atherosclerosis.

3. Mechanical: vibration (white hand vibration syndrome), crutch pressure, thoracic outlet syndrome, scalenus anticus syndrome, cervical rib, carpal tunnel syndrome.

4. Temperature: frostbite

5. Endocrine disorders: carcinoid syndrome, pheochromocytoma, hypothyroidism

6. Neoplasia: ovarian carcinoma, angiocentric lymphoma.

7. Rheological and coagulation disorders: cryoglobulins, cryofibrinogenemia, cold agglutinins, paraproteinemia, plasmacytoma, polycythemia, microthromboembolism.

8. Infections: parvovirus B19, helicobacter pylori, hepatitis C and B, mycoplasma (cold agglutinins).

9. Medications $=>$ see table III

This article is protected by copyright. All rights reserved 


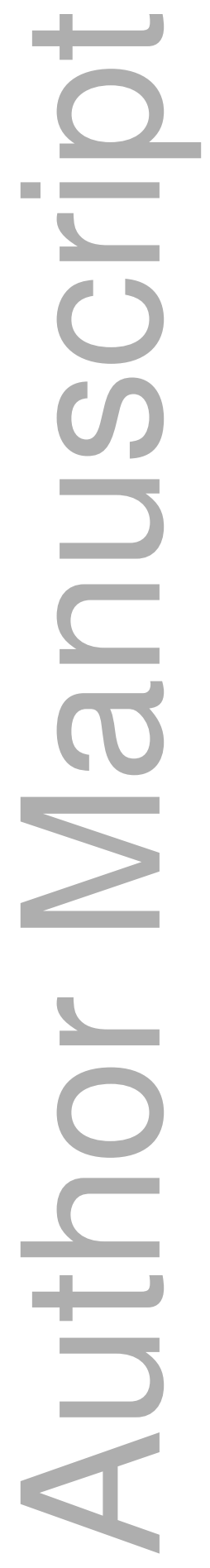

Table III : Drugs inducing Raynaud's phenomenon

This article is protected by copyright. All rights reserved 
Drugs can induce RP mainly through 3 known mechanisms: enhanced vasoconstriction, endothelial damage or neurotoxicity and increased blood viscosity

\begin{tabular}{|c|c|}
\hline Drug & Mechanism \\
\hline$\beta$-blockers & $\begin{array}{l}\text { Vasoconstriction via beta-adrenoreceptor blockade but still } \\
\text { unclear. }\end{array}$ \\
\hline Clonidine & $\begin{array}{l}\alpha 2 \text {-adrenoreceptor agonist. In RP we already find a cold- } \\
\text { amplified } \alpha 2 \text {-mediated vasoconstriction, augmented by } \\
\text { clonidine action. ( } \alpha 2 \text { receptor are located on smooth muscle } \\
\text { cells) }\end{array}$ \\
\hline Ergot alkaloic & 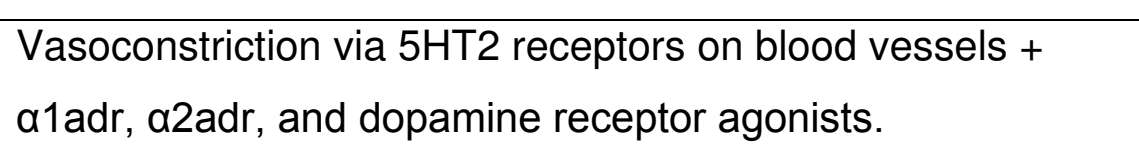 \\
\hline Dopamine agonists & $\begin{array}{l}\text { Such as bromocriptine, share the same mechanism as ergot } \\
\text { alkaloids at high doses. }\end{array}$ \\
\hline $\begin{array}{l}\text { Central stimulators of } \\
\text { dopaminergic and } \\
\text { noradrenergic system }\end{array}$ & $\begin{array}{l}\text { Peripheral release of catecholamines } \\
\text { i.e. methylphenidate and dextroamphetamine, atomoxetine, } \\
\text { reboxetine; amphetamine-like drugs like phentermine }\end{array}$ \\
\hline Cyclosporir & $\begin{array}{l}\text { Unclear, maybe vasospastic effect and alteration in blood } \\
\text { viscosity }\end{array}$ \\
\hline Cocaine & a2-adrenoreceptor mediated vasoconstriction \\
\hline Chemotherapies & $\begin{array}{l}\text { 3-6 months after starting. Drugs: bleomycin, vinca alkaloids, } \\
\text { cisplatin mainly, less known for other therapies, }\end{array}$ \\
\hline Vinyl Chloride & Occupational and/or environmental exposure \\
\hline Interferons (IFNs) & $\begin{array}{l}\text { IFN } \alpha>\mathrm{IFN} \beta>\mathrm{IFN} \gamma \text {, unclear, probably enhances } \\
\text { vasoconstriction and increases blood viscosity. }\end{array}$ \\
\hline Tyrosine Kinase Inhibitors & Unknown \\
\hline Potentially RP inducers & Few cases in literature \\
\hline $\begin{array}{l}\text { Selective Serotonine } \\
\text { Reuptake Inhibitors (SSRI) }\end{array}$ & $\begin{array}{l}\text { Contradictory data in the literature, apparently it depends on } \\
\text { variability in serotonin patterns }\end{array}$ \\
\hline Sympathomimetics & i.e. ephedrine. Only 1 patient reported in literature \\
\hline Sulfasalazine & Unknown mechanism \\
\hline Amphotericin B & Unknown mechanism \\
\hline
\end{tabular}




\begin{tabular}{|l|l|}
\hline Propofol & Unknown mechanism \\
\hline
\end{tabular}

Table IV: Physical characteristics of Raynaud's phenomenon, Erythromelalgia, Acral Cyanosis, and Livedo Reticularis

This article is protected by copyright. All rights reserved 


\begin{tabular}{|c|c|c|c|c|}
\hline & \begin{tabular}{|l} 
Raynaud's \\
phenomenon
\end{tabular} & $\begin{array}{l}\text { Acral } \\
\text { Cyanosis }\end{array}$ & Erythromelalgia & Livedo Reticularis \\
\hline Classification & Primary / secondary & $\begin{array}{l}\text { Primary / } \\
\text { secondary }\end{array}$ & $\begin{array}{ll}\text { - } & \text { Familial, } \\
& \text { (autosomal } \\
& \text { dominant) } \\
\text { - } & \text { Sporadic } \\
\text { - } & \text { Juvenile/adult }\end{array}$ & Primary / secondary \\
\hline $\begin{array}{l}\text { Phases of color } \\
\text { change }\end{array}$ & $\begin{array}{l}\text { Bi-triphasic/ } \\
\text { white,blue,red }\end{array}$ & $\begin{array}{l}\text { Monophasic / } \\
\text { dark blue }\end{array}$ & $\begin{array}{l}\text { Monohasic } \\
\text { /erythematous }\end{array}$ & $\begin{array}{l}\text { Macular, violaceous, } \\
\text { netlike rings }\end{array}$ \\
\hline Laterality & $\begin{array}{l}\text { Primary-bilateral \& } \\
\text { symmetrical } \\
\text { Secondary- } \\
\text { mono/bilateral } \\
\text { asymmetric }\end{array}$ & Mono/bilateral & Bilateral & Bilateral \\
\hline Pain & ++ & Uncommon & ++++ & - \\
\hline Limb & $\begin{array}{l}\text { Hands, feet, nose, ears, } \\
\text { tongue }\end{array}$ & Hands, feet & $\begin{array}{l}\text { Feet (may extend to } \\
\text { hand, ears and } \\
\text { nose) }\end{array}$ & $\begin{array}{l}\text { Upper and lower } \\
\text { limbs }\end{array}$ \\
\hline $\mathbf{T}^{\circ}$ extremities & Cold & Cold & Hot & Cold \\
\hline Precipitated by & & $\begin{array}{l}\text { Cold \& } \\
\text { lowering of the } \\
\text { limb }\end{array}$ & Hot & Cold \\
\hline Phase/duration & $\begin{array}{l}\text { Paroxistic/lasts from } \\
\text { minutes to hours }\end{array}$ & $\begin{array}{l}\text { Chronic/ } \\
\text { seasonal } \\
\text { (amelioration in } \\
\text { summer) }\end{array}$ & $\begin{array}{l}\text { Intermittent/ may last } \\
\text { from minutes to days }\end{array}$ & $\begin{array}{l}\text { Primary:chronic } \\
\text { Secondary- acute/ } \\
\text { intermittent/chronic }\end{array}$ \\
\hline hyperhydrosis & & +++ & Significant reduction & $-\cdots$ \\
\hline $\begin{array}{l}\text { Modification of } \\
\text { the } \\
\text { phenomenon } \\
\text { with the } \\
\text { position of the } \\
\text { limb }\end{array}$ & No change & $\begin{array}{l}\text { Normalizes } \\
\text { when limb is } \\
\text { elevated }\end{array}$ & No change & No change \\
\hline Complications & $\begin{array}{l}\text { Digital Ulcers, } \\
\text { gangrene, amputation }\end{array}$ & None & None & $\begin{array}{l}\text { None in primary, } \\
\text { in secondary } \\
\text { possible necrosis }\end{array}$ \\
\hline
\end{tabular}




\begin{tabular}{|l|l|l|l|l|}
\hline & & & & and gangrene \\
\hline
\end{tabular}

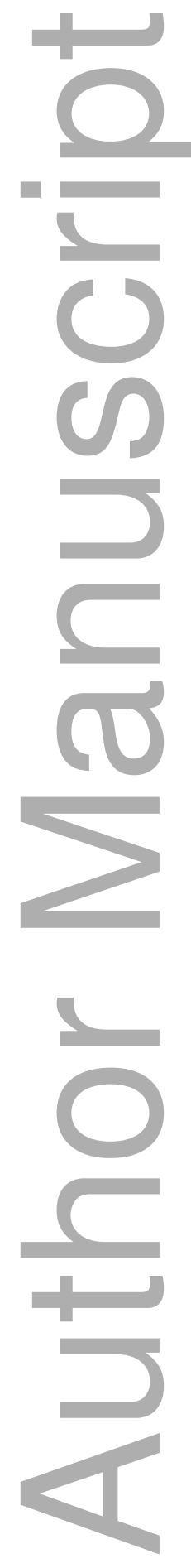

This article is protected by copyright. All rights reserved 
Table V: Therapies for Raynaud phenomenon

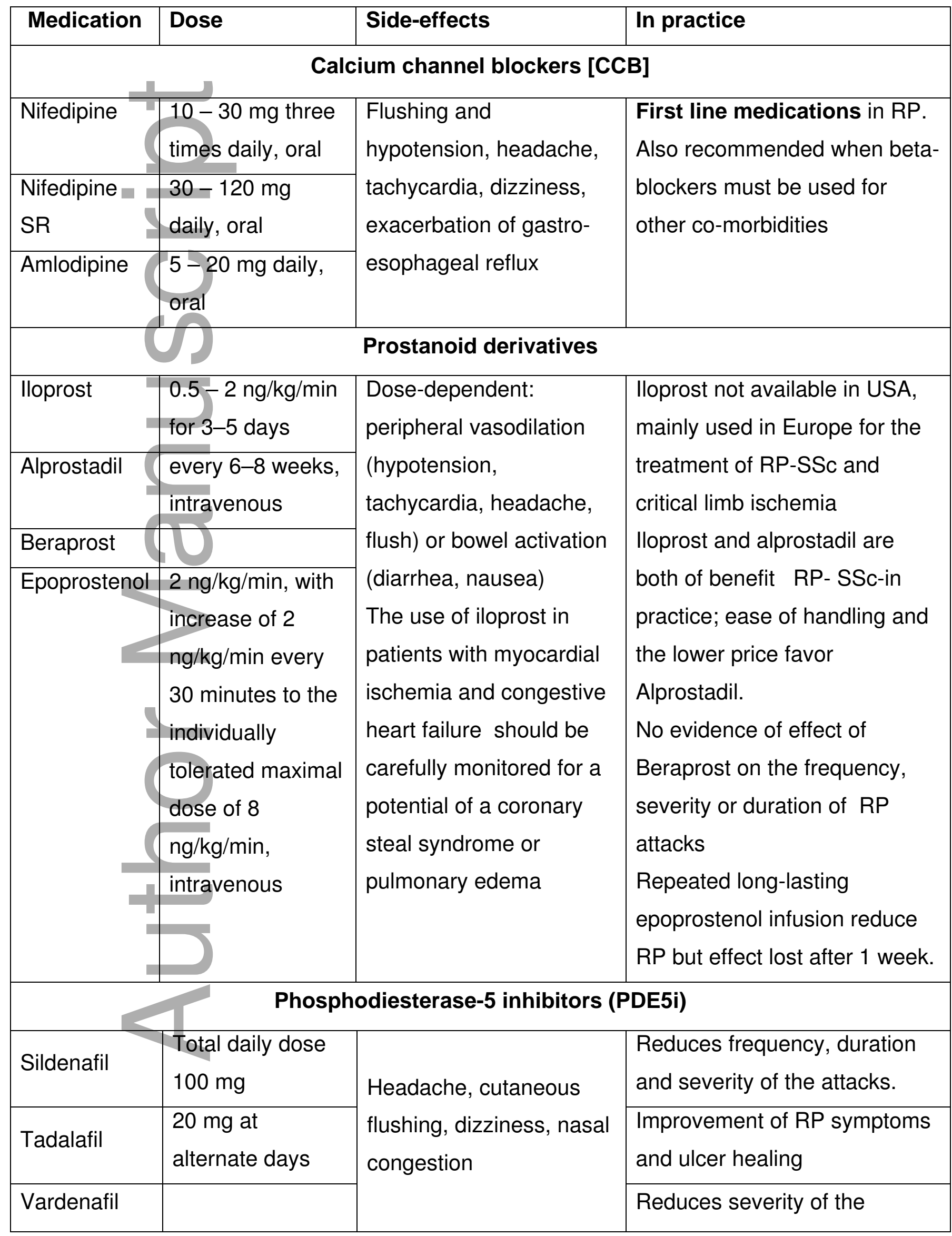

This article is protected by copyright. All rights reserved 


\begin{tabular}{|c|c|c|c|}
\hline & & & $\begin{array}{l}\text { attacks and improves } \\
\text { Raynaud's Condition Score }\end{array}$ \\
\hline \multicolumn{4}{|c|}{ Endothelin receptor antagonists (ERA) } \\
\hline Bosentan & 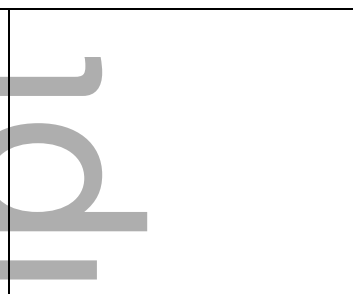 & & $\begin{array}{l}\text { Did not reduce frequency } \\
\text { duration and pain of the } \\
\text { attacks but prevented } \\
\text { recurrence of DUs. }\end{array}$ \\
\hline & Drugs interfe & ng with intracellular c & ium activity \\
\hline Minoxidil & $\begin{array}{l}\text { topical minoxidil } \\
5 \% \text { solution }\end{array}$ & & $\begin{array}{l}\text { Not effective in improving } \\
\text { baseline digital blood flow or } \\
\text { cold tolerance in RP }\end{array}$ \\
\hline \multicolumn{4}{|c|}{ Sympathetic blockade } \\
\hline Prazosin & $\begin{array}{l}1-5 \mathrm{mg} \text { two } \\
\text { times daily, oral }\end{array}$ & $\begin{array}{l}\text { Dizziness, hypotension } \\
\text { and syncope }\end{array}$ & $\begin{array}{l}\text { Modest effect on RP. } \\
\text { Reduction of the attacks and } \\
\text { DUs healing. }\end{array}$ \\
\hline $\begin{array}{l}\text { Botulinum } \\
\text { toxin - A }\end{array}$ & $\begin{array}{l}\text { Dose dependent } \\
\text { vasodilation with } \\
\text { 10-100 units } \\
\text { injections }\end{array}$ & & $\begin{array}{l}\text { Favorable results in many } \\
\text { studies despite limitations. } \\
\text { Improving of pain, severity, } \\
\text { and reduction of DUs } \\
\text { frequency }\end{array}$ \\
\hline \multicolumn{4}{|c|}{ Angiotensin - II receptor blocker } \\
\hline Losartan & $\begin{array}{l}25-100 \mathrm{mg} \\
\text { daily, oral }\end{array}$ & Dizziness, hypotension & $\begin{array}{l}\text { One trial showed benefit in } \\
\text { SSc patients with RP but } \\
\text { seldom employed in practice }\end{array}$ \\
\hline \multicolumn{4}{|c|}{ Serotonin re-uptake inhibitor } \\
\hline Fluoxetine & $\begin{array}{l}20-40 \mathrm{mg} \text { daily, } \\
\text { oral }\end{array}$ & $\begin{array}{l}\text { Apathy, lethargy and } \\
\text { impaired concentration }\end{array}$ & $\begin{array}{l}\text { One trial showed benefit in } \\
\text { SSc patients with RP but } \\
\text { seldom employed in practice }\end{array}$ \\
\hline \multicolumn{4}{|c|}{ Phosphodiesterase - 3 inhibitor } \\
\hline Pentoxifylline & $400-1200 \mathrm{mg}$ & Dizziness, hypotension, & Has anti-platelet aggregation \\
\hline
\end{tabular}

This article is protected by copyright. All rights reserved 


\begin{tabular}{|c|l|l|l|}
\hline \multicolumn{2}{|c|}{ daily, oral } & nausea, diarrhea & property \\
\hline \multicolumn{3}{|c|}{ Topical nitroglycerine } \\
\hline $\begin{array}{c}\text { Nitroglycerine } \\
\text { patches }\end{array}$ & $\begin{array}{l}0,2 \mathrm{mg} / \mathrm{h} \text { (slow } \\
\text { release) }\end{array}$ & Headache & $\begin{array}{l}\text { Reduction of number and } \\
\text { severity of the attacks }\end{array}$ \\
\hline $\begin{array}{c}0,9 \% \\
\text { nitroglycerine } \\
\text { gel }\end{array}$ & & $\begin{array}{l}\text { Improvement in frequency and } \\
\text { duration of the attacks and of } \\
\text { RPS }\end{array}$ \\
\hline \multicolumn{3}{|c|}{ Combination therapy: PDE5i + ERA } \\
\hline \begin{tabular}{l} 
Bosentan + sildenafil \\
\hline
\end{tabular} & $\begin{array}{l}\text { Reduction of late and active capillaroscopic } \\
\text { patterns, improvement of the RP }\end{array}$ \\
\hline
\end{tabular}

Figure 1: Asymmetric Raynaud's phenomenon in a 28-year-old woman (blanching phase)

Figure 2: a stepwise approach to RP evaluation Abbreviations: $\mathrm{NC}=$ nail fold capillaroscopy, $\mathrm{DU}=$ digital ulcers, $\mathrm{SSc}=$ systemic sclerosis, $\mathrm{SLE}=$ systemic lupus erythematosus, $E M G=$ electromyography, NCV = Nerve Conduction Velocity, $\mathrm{TSH}=$ thyroid stimulating hormone, $\mathrm{TPO}=$ thyroperoxidase, $\mathrm{TG}=$ thyroglobulin, $\mathrm{HCV}=$ Hepatitis $\mathrm{C}$ Virus, $\mathrm{BUN}=$ blood urea nitrogen 
Figure 3: Raynaud phenomenon in a 28-year-old woman with antinuclear and anticentromere antibodies positivity, active capillaroscopy pattern with one micro-hemorrhage (insert a). She was diagnosed with very early systemic sclerosis. The digital swelling worsened with the development of a digital ulcer in the third finger (insert b).

Figure 4: Raynaud phenomenon in a 57-year-old woman with puffy fingers. In the two inserts, capillaroscopy shows micro hemorrhages (a) and mega capillaries (b). The patient had antinuclear and anti-centromere antibodies without any skin fibrosis. A diagnosis of very early systemic sclerosis was made.

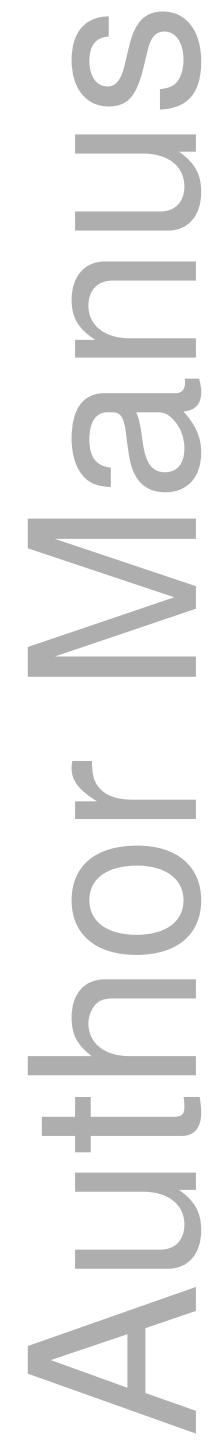

This article is protected by copyright. All rights reserved 


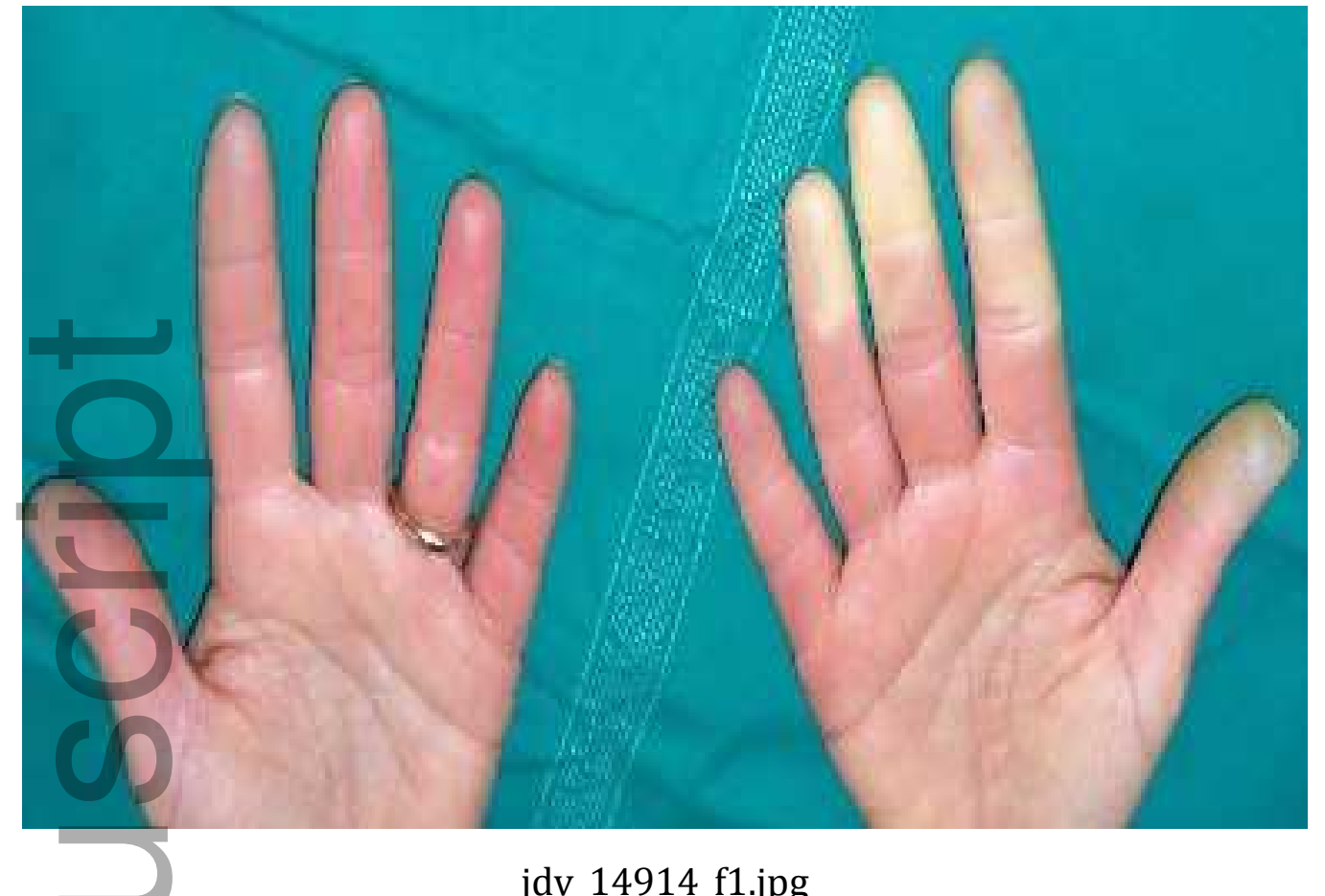

jdv_14914_f1.jpg

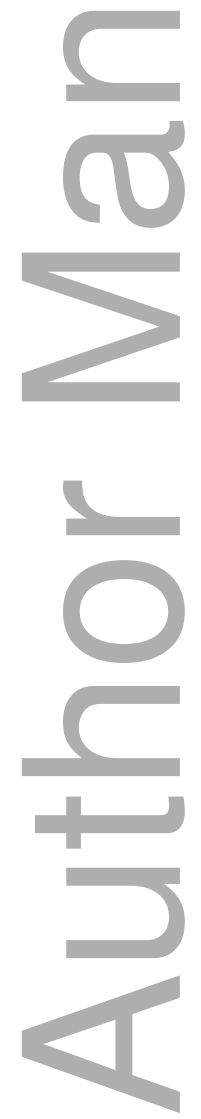

This article is protected by copyright. All rights reserved 


\section{Raynaud phenomenon}

Clinical history, attacks (symmetry, frequency), medications, occupation $\downarrow$

\begin{tabular}{|c|c|c|c|c|}
\hline \multicolumn{5}{|c|}{ Clinical assessment } \\
\hline \multicolumn{5}{|c|}{ 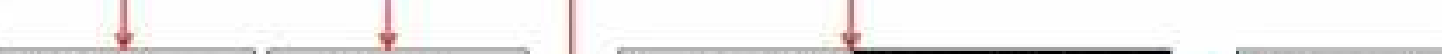 } \\
\hline Puffy fingers & \multirow{2}{*}{$\begin{array}{l}\text { Myopathy } \\
\text { Skin rash }\end{array}$} & Smoking, DU & Buerger's disease & Angiography \\
\hline Skin thickening & & & & \\
\hline Telangiectasia & Oral ulcers & Paresthesia & & EMG / NCV \\
\hline Abnomal NC: & Arthritis & & Carpal tunnel & \\
\hline DU & Alopecia & Postural & \multirow[t]{2}{*}{ Outlet syndrome } & Neck $x$-ray \\
\hline SSC & SLE / myositis & variations & & CT thorax \\
\hline \multicolumn{2}{|c|}{$\begin{array}{c}\text { Serologies } \\
\text { Assess extent of involvement }\end{array}$} & & & \\
\hline & & & & \\
\hline \multicolumn{5}{|c|}{ Abnormal laboratory work-up } \\
\hline $\begin{array}{l}\text { High TSH, low T4 } \\
\text { TPO AD } \\
\text { TG AD }\end{array}$ & \multirow{2}{*}{\multicolumn{2}{|c|}{$\begin{array}{c}\text { Anti-HCV } \\
\text { Rheumatoid factor } \\
\text { Cryoglobulins } \\
\text { Hypergammaglobulinemia }\end{array}$}} & \multirow{2}{*}{\multicolumn{2}{|c|}{$\begin{array}{l}\text { Monoclonal gammopathy } \\
\text { Bence Jones proteinuria } \\
\text { Elevated BUN / Creatinine } \\
\text { Anemia }\end{array}$}} \\
\hline \multirow{2}{*}{$\begin{array}{l}\text { Hypothyroidism } \\
\text { Thyroiditis }\end{array}$} & & & & \\
\hline & \multicolumn{2}{|c|}{ Cryoglobulinemia } & \multicolumn{2}{|c|}{ Multiple myeloma } \\
\hline
\end{tabular}

jdv_14914_f2.jpg 

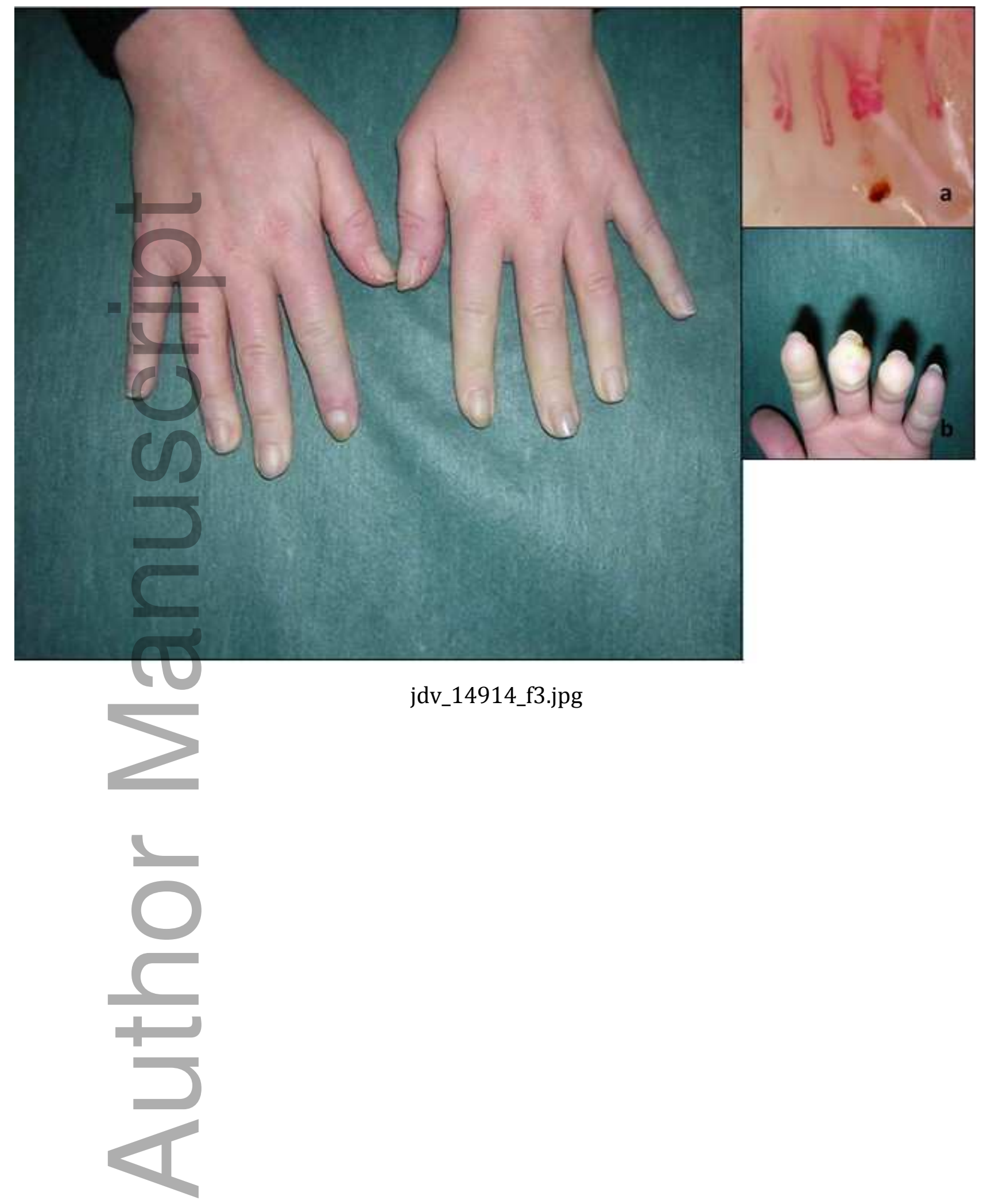

This article is protected by copyright. All rights reserved 


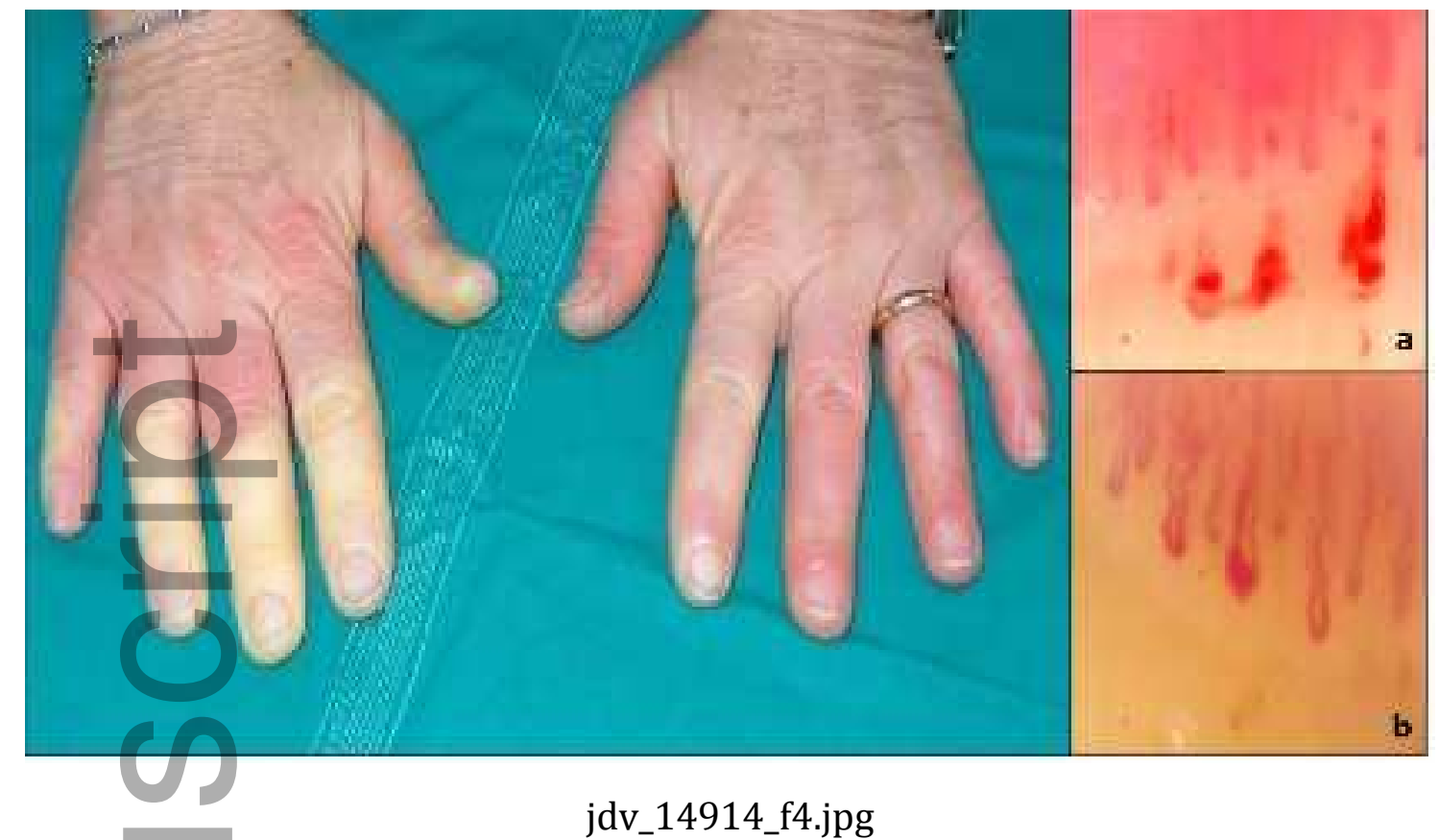

jdv_14914_f4.jpg

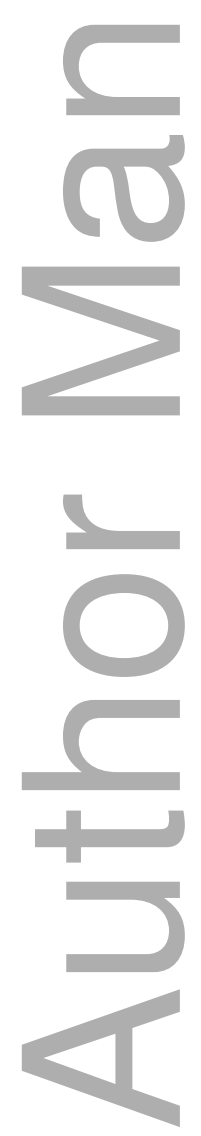

This article is protected by copyright. All rights reserved 